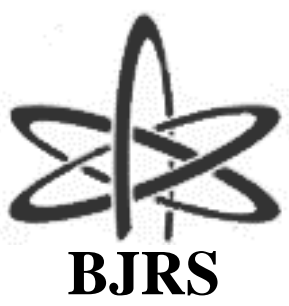

\author{
BRAZILIAN JOURNAL \\ $\mathrm{OF}$ \\ RADIATION SCIENCES \\ 07-02A (2019) 01-13
}

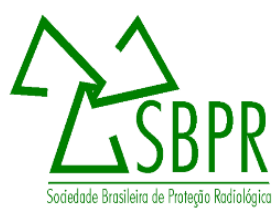

\title{
Chemical characterization of urban park soils of the metropolitan region of São Paulo
}

\author{
Figueiredo $^{\mathrm{a}}$ A. M. G., Enzweiler ${ }^{\mathrm{b}}$ J., Lange ${ }^{\mathrm{a}}$ C. N., Sígolo ${ }^{\mathrm{c}}$ J.B. \\ ${ }^{a}$ Instituto de Pesquisas Energéticas e Nucleares (IPEN / CNEN - SP), 05508-000, São Paulo, SP, Brazil \\ ${ }^{b}$ Instituto de Geociências da Universidade Estadual de Campinas - UNICAMP, 13083-870, Campinas, SP, Brazil \\ ${ }^{c}$ Instituto de Geociências da Universidade de São Paulo - USP, 05508-080, São Paulo, SP, Brazil \\ anamaria@ipen.br
}

\begin{abstract}
In the last years, urban soils have been increasingly subject of investigations concerning their description and composition. In several important cities all over the world, urban soils show a significant increase in metal levels, due to the rise of pollution originated from continuous urbanization and industrial development. This metal contamination can disturb the natural geochemical cycles and their depending ecosystems. The expected population growth during the next decades will concentrate in urban areas, which are already the predominant human habitat. Metal contamination is a key issue in São Paulo City, the biggest urban agglomeration in Latin America. There has been little research on metal levels in São Paulo urban soils and almost nothing related to the city's parks. The present study presents the concentration of major and trace elements in soil samples of nine parks of the metropolitan region of São Paulo. Topsoil samples $(0-20 \mathrm{~cm})$ were collected in lines across the parks in order to have representative samples of the entire park. Instrumental Neutron Activation Analysis (INAA) and X-ray Fluorescence (XRF) were used for whole elemental analysis. The outcome of this study showed that the soils of the public parks studied presented, in general, concentration levels higher than the reference values for soils in São Paulo State. For As, V and Ni, which showed significant enrichment factors in relation to reference values, there is an indication of anthropogenic source. Cluster analysis grouped the elements $\mathrm{Zn}, \mathrm{Sb}, \mathrm{Pb}$ and $\mathrm{Cu}$, well known as traffic-related elements, which may indicate a vehicular source.
\end{abstract}

Keywords: urban parks soils, chemical characterization, neutron activation analysis.

ISSN: 2319-0612

Accept Submission: 2018-12-03 


\section{INTRODUCTION}

In the last years, urban soils have been increasingly subject of investigations that include their chemical characterization. As a result, a significant increase in metal levels in urban soils as compared to non urban soils was observed in cities such as Madrid [1], Palermo [2], Naples [3], Hong Kong [4], Torino [5], Lisbon [6], and many others, due to the rise of metal pollution originating from continuous traffic and industrial related sources. Ajmone-Marsan and Biasoli [7] reviewed 153 studies published during a recent period of 10 years, in which the urban environment was assessed and trace elements in soils of 94 world cities were investigated. According to those authors, the high data variability among the studies derives from the variety of land uses, number of samples, the depth of sample collection and also sample treatments and analytical methods.

The distribution of trace elements in soils is controlled by biogeochemical processes related to parameters such as metal solubility and physicochemical characteristics of the soil, especially for non-disturbed soils. Natural and non-disturbed soils mostly allow water percolation, which may transport trace metals through the soil profile, either as dissolved species or sorbed to fine particles, which eventually may be trapped by soil components. In urban soils, however, surface runoff is the main water flow mechanism because percolation is significantly reduced by impervious surfaces. In principle, any extra metal input can disturb the natural biogeochemical cycle of ecosystems [8], specialty because several activities affect soils in urban areas. Therefore, it is expected that the ability of the terrestrial environment of fixing or immobilizing contaminant metals is limited in comparison to the natural environment [9].

The expected population growth during the next decades will take place in urban areas, with almost no growth in the rural population [9]. It is estimated that by the year 2050 about $70 \%$ of the global population will live in cities. Thus, the urban environment will become the predominant human habitat.

Metals are not biodegradable and accumulate in nature. The prolonged presence of the contaminants in the urban environment, particularly in urban soils, and the proximity to city inhabitants can cause harmful exposure to metals through inhalation, ingestion, and dermal [10-13]. Children, obvi- 
ously, are more susceptible to the adverse effects of soil ingestion or inhalation than adults because their nervous system is under development and higher absorption rate [2, 13].

Metal contamination is an important environmental issue in São Paulo City, the biggest city in Latin America, but there is almost nothing related to the city's parks. A study concerning metal levels in São Paulo urban soils [14] and data from topsoil samples $(0-5 \mathrm{~cm})$ from seven urban parks of São Paulo [15] have already been reported.

São Paulo city has suffered a rapid and disordered growth in the last decades, which has led to considerable loss in agricultural soils and urban green spaces. Therefore, São Paulo public parks play an important role as leisure areas for the population, mainly for children. The present study presents the concentration of major and trace elements in soil samples of nine parks of the metropolitan region of São Paulo.

\section{MATERIALS AND METHODS}

The Metropolitan region of São Paulo, RMSP, is located at $23^{\circ} \mathrm{S}$ and $46^{\circ} \mathrm{W}$ in the southeastern region of Brazil. It covers an area of $8,051 \mathrm{~km}^{2}$, with about 21 million inhabitants. The RMSP occupies about $0.1 \%$ of the Brazilian territory and is the third largest urban conglomerate in the world, responsible for $1 / 6$ of the gross national product [16]. According to CETESB, the Environmental Protection Agency of the State of São Paulo, the RMSP suffers from all kinds of environmental problems. The main contributions to atmospheric emissions come from about 2,000 highly polluting industries and an ever increasing 7 million vehicle fleet [17]. Nine public parks of São Paulo, covering different regions of the city, were studied (Fig. 1).

\subsection{Sampling Strategy}

The soil samples were collected between October 2006 and April 2007. Topsoil samples (0-20 $\mathrm{cm}$ ) were collected in lines across the park every $30 \mathrm{~m}$, providing 10-15 samples of about $500 \mathrm{~g}$ each in each park. Sampling aimed to represent the most of each park area, mainly covering sites where the flux of people is more intense, such as jogging paths, sport and leisure areas. A polyethylene tube with $4 \mathrm{~cm}$ diameter was used to take the samples, which were stored in inert plastic bags. 
In the laboratory, the samples were dried at $40^{\circ} \mathrm{C}$ and sieved through plastic-only sieves, to separate the $<2 \mathrm{~mm}$ fractions. Before and after sieving, the samples were homogenized and quartered. The samples were ground using an agate mortar in order to obtain a fine and homogeneous powder $(<$ $75 \mu \mathrm{m})$.

Figure 1: Localization of the studied parks in São Paulo city.

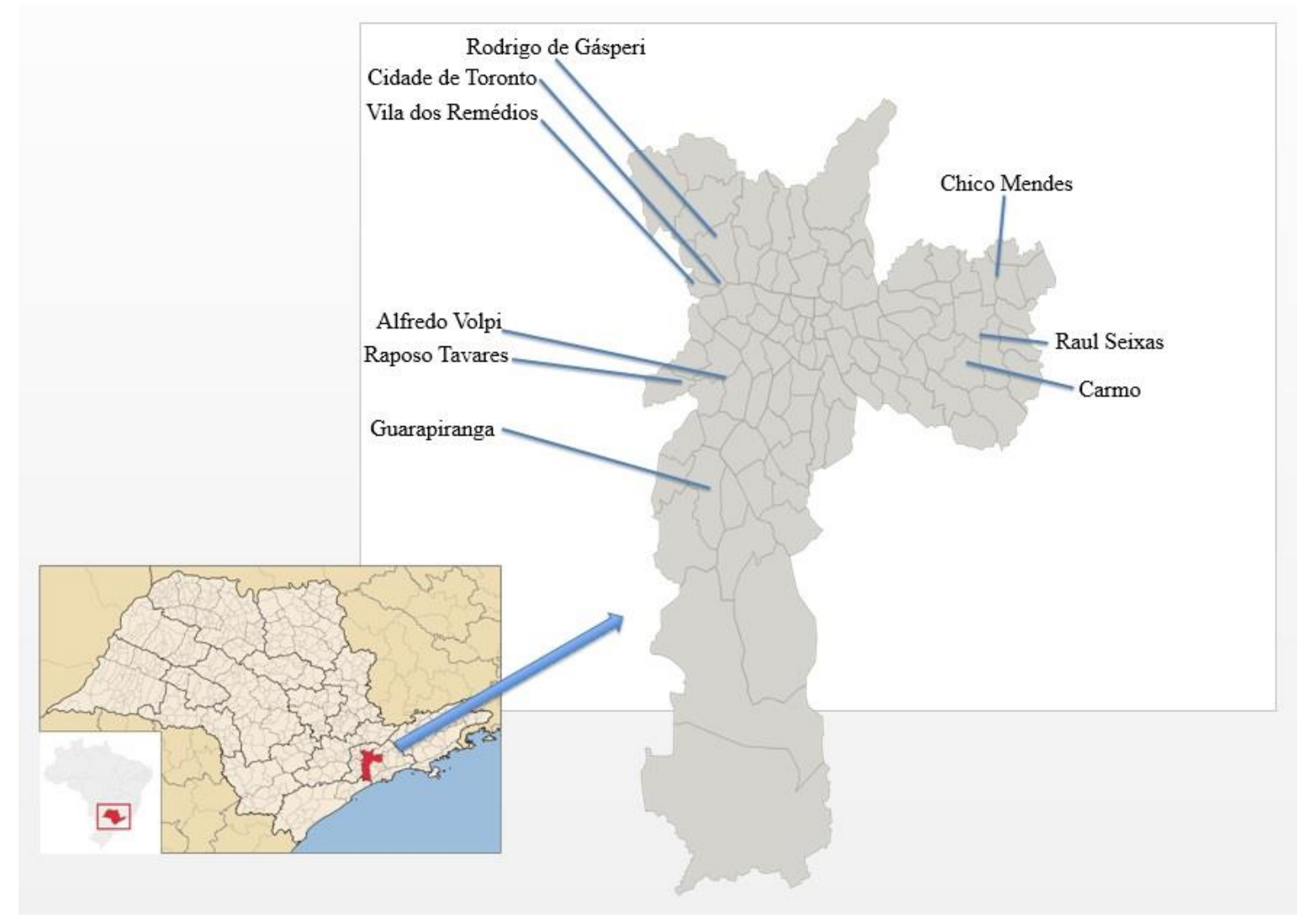

\subsection{Soil Properties}

The soil samples contained 40 to $88 \%$ of clay-silt particles $(<0.063 \mathrm{~mm})$. The amount of fine grain size is characteristic of samples from the eastern area of the city. The $\mathrm{pH}$ values of the soil samples ranged from 3.3 to 6.8 , but most of the values were around 4.5-5.0, indicating acid soils. The content of total organic carbon in the soil ranged between 1.2 to $8.3 \%$.

\subsection{Analytical Methods}


Instrumental Neutron Activation Analysis (INAA) and X-ray Fluorescence (XRF) were used for whole elemental analysis. Instrumental neutron activation analysis (INAA) was employed to analyse the elements As, Ba, Co, Cr, Sb and $\mathrm{Zn}$, as well as Cs, Fe, Hf, Rb, Sc, Ta, Th, U and the lanthanides ( $\mathrm{La}, \mathrm{Ce}, \mathrm{Nd}, \mathrm{Sm}, \mathrm{Tb}, \mathrm{Yb}$ and $\mathrm{Lu}$ ). One hundred to one hundred and fifty $\mathrm{mg}$ of each sample and of the geological reference materials basalt BE-N (ANRT), granite GS-N (ANRT) and, for quality control, SOIL-7 (IAEA), were accurately weighed in polyethylene bags. Samples and reference materials were irradiated for 8 hours at a thermal neutron flux of $1013 \mathrm{n} \mathrm{cm}^{-2} \mathrm{~s}^{-1}$ at the IEA-R1 nuclear reactor of IPEN.

The measurements of the induced gamma-ray activity were carried out using a gamma-ray spectrometer with a GX20190 hyperpure Ge detector (Canberra). The analysis of the certified reference material Soil-7 (IAEA) provided measurement bias $(<5 \%)$ and coefficients of variation $(<15 \%)$. X-ray florescence spectrometry (XRF) was employed to determine $\mathrm{Cu}, \mathrm{Ga}, \mathrm{Ni}, \mathrm{Nb}, \mathrm{Mo}, \mathrm{Se}, \mathrm{Sn}, \mathrm{Sr}$, $\mathrm{Pb}, \mathrm{V}, \mathrm{Zr}$, Y and the oxides $\mathrm{Al}_{2} \mathrm{O}_{3}, \mathrm{Fe}_{2} \mathrm{O}_{3}, \mathrm{MnO}, \mathrm{MgO}$ and $\mathrm{CaO}$, among others. Pellets (40 mm diameter) consisting of a mixture of $9 \mathrm{~g}$ of the sample and $1.5 \mathrm{~g}$ of powdered wax (Hoechst) were prepared and measured using a WD-XRF spectrometer (PW2404, Philips) [18]. The accuracy and precision of the results were verified by the analysis of the reference materials GSS-2 and GSS-4 (soil, Institute of Geophysical and Geochemical Exploration, China). Measurement bias and coefficients of variation were better than $10 \%$.

\section{RESULTS AND DISCUSSION}

The results obtained are presented in Table I. Most of the studies on urban soils are focused in the potentially toxic elements $\mathrm{As}, \mathrm{Co}, \mathrm{Cr}, \mathrm{Cu}, \mathrm{Ni}, \mathrm{Pb}$ and $\mathrm{Zn}$, and there is not much information about other trace elements, such as rare earth elements, $U$ and $T h$. The data are a contribution to the knowledge of the concentration of trace and major elements in urban park soils of São Paulo, since there is still little information on São Paulo urban soils composition. For comparison, some literature data are presented in Table I. Several studies on trace metals in urban soils have been reported for many other cities in the world, the majority of them in the soils of European cities, where the main sources of pollution have been from industry and/or traffic emissions. Table I presents, for 
comparison, the results of the average of trace metals of 34 European cities [19], more recent results from Lisbon [6] and the average values of 21 Chinese cities [19].

Considering the elements $\mathrm{As}, \mathrm{Co}, \mathrm{Cr}, \mathrm{Cu}, \mathrm{Ni}, \mathrm{Pb}$ and $\mathrm{Zn}$, in relation to Chinese and European soils, only As presented significant higher values, in Chico Mendes and Vila dos Remédios parks. There is little information on background concentrations of As in urban soils [20]. Kabata-Pendias and Pendias [21] report soil arsenic concentrations in undisturbed areas between 0.1 and $40 \mathrm{mg} \mathrm{kg}^{-1}$ worldwide, with an arithmetic mean concentration of 5 to $6 \mathrm{mg} \mathrm{kg}^{-1}$. Chirenje et al. [20] report As concentrations in Gainesville soils, in Florida, ranging from 0.21 to approximately $660 \mathrm{mg} \mathrm{kg}^{-1}$, and from 0.32 to $110 \mathrm{mg} \mathrm{kg}^{-1}$ in Miami soils, depending on the land-use classes (residential, commercial, and public land).

According to the EPA Preliminary Remediation Goals (PRGs) [22], As levels of $4.5 \mathrm{mg} \mathrm{kg}^{-1}$ may cause cancer risk of one per million through dermal absorption. A possible source of As is its use in fertilizers and pesticides. Chromated copper arsenate (CCA) treated wood is widely used in the fabrication of outdoor decks and playground equipment's and is a source of arsenic contamination for soils and groundwater [23]. Considering the trigger value for direct exposition for children soil parks (25 mg kg-1, according to the German Federal Legislation of Soil Protection [24]), it can be noticed that the As concentration in Chico Mendes park requires a further investigation to identify if there is indeed danger or contamination. Antimony and V are considered traffic related elements, and these results suggest that fuel combustion may be a source of this element in the soils. In relation to Lisbon soils, Sc, Th, U, Ga and La presented higher values. These elements are not usually related to anthropogenic sources, and the results may be may be attributed to the lithology of São Paulo. 
Table I: Mean Values of Topsoil Metal Concentration in Public Parks of São Paulo and Literature Values $\left(\mathrm{mg} \mathrm{kg}^{-1}\right)$.

\begin{tabular}{|c|c|c|c|c|c|c|c|c|c|c|c|c|}
\hline & $\begin{array}{l}\text { Chico } \\
\text { Mendes }\end{array}$ & Carmo & $\begin{array}{c}\text { Cidade } \\
\text { de } \\
\text { Toronto }\end{array}$ & Guarapiranga & $\begin{array}{l}\text { Rodrigo } \\
\text { Gáspari }\end{array}$ & $\begin{array}{c}\text { Raul } \\
\text { Seixas }\end{array}$ & $\begin{array}{l}\text { Vila dos } \\
\text { Remédios }\end{array}$ & $\begin{array}{l}\text { Raposo } \\
\text { Tavares }\end{array}$ & $\begin{array}{c}\text { Alfredo } \\
\text { Volpi }\end{array}$ & $\begin{array}{c}\text { Lisbon } \\
\text { [6] }\end{array}$ & $\begin{array}{c}21 \\
\text { Chinese } \\
\text { Cities } \\
{[19]} \\
\end{array}$ & $\begin{array}{c}34 \\
\text { European } \\
\text { Cities } \\
{[19]} \\
\end{array}$ \\
\hline As & 31 & 5.4 & 6.9 & 4.9 & 16 & 3.5 & 24.5 & 10 & 8.1 & 5.3 & 12 & 13 \\
\hline $\mathbf{B a}$ & 102 & 79 & 570 & 289 & 628 & 95 & 221 & 115 & 166 & 107 & & \\
\hline $\mathrm{Ce}$ & 63 & 51 & 116 & 130 & 145 & 60 & 108 & 85 & 85 & & & \\
\hline Co & 2.2 & 2.3 & 5.0 & 6.5 & 5.9 & 2.0 & 3.6 & 3.1 & 10 & 13 & 14 & 6.4 \\
\hline $\mathrm{Cr}$ & 88 & 34 & 37 & 60 & 47 & 45 & 80 & 60 & 50 & 38 & 69 & 59 \\
\hline Cs & 3.7 & 1.6 & 2.2 & 4.1 & 1.9 & 1.3 & 2.3 & 2.3 & 3.7 & & & \\
\hline $\mathrm{Cu}$ & 27 & 13 & 23 & 22 & 21 & 17 & 28 & 37 & 23 & 37 & 40 & 46 \\
\hline $\mathbf{E u}$ & 0.46 & 0.20 & 1.85 & 1.09 & 1.99 & 0.22 & 0.90 & 0.51 & 0.50 & & & \\
\hline Ga & 32 & 22 & 29 & 21 & 31 & 22 & 34 & 34 & 25 & 4.0 & & \\
\hline Hf & 13 & 7.3 & 15.5 & 12 & 16 & 7.9 & 18 & 12 & 10 & & & \\
\hline La & 31 & 13 & 62 & 50 & 67 & 10.6 & 54 & 26.6 & 40 & 16 & & \\
\hline Lu & 0.40 & 0.23 & 0.30 & 0.54 & 0.35 & 0.19 & 0.39 & 0.48 & 0.44 & & & \\
\hline Mo & 4.8 & 2.3 & 4.4 & 2.8 & 5.3 & 2.0 & 8.0 & 4.5 & 3.0 & 0.67 & & \\
\hline $\mathrm{Nb}$ & 27 & 12 & 22 & 21 & 26 & 14 & 33 & 31.5 & 28 & & & \\
\hline Nd & 15 & 6.4 & 48 & 47 & 54 & 5.4 & 34 & 21 & 21 & 43 & & \\
\hline $\mathbf{N i}$ & 9.4 & 7.2 & 9.4 & 14 & 12 & 3.6 & 15 & 20 & 13 & 89 & 25 & 22 \\
\hline $\mathbf{P b}$ & 38 & 18 & 40 & 31 & 40 & 24 & 40 & 35 & 58 & & 55 & 102 \\
\hline $\mathbf{R b}$ & 22 & 10 & 42 & 50 & 30 & 16 & 23 & 20 & 30 & 0.84 & & \\
\hline $\mathbf{S b}$ & 1.34 & 0.37 & 0.55 & 0.54 & 0.99 & 0.23 & 1.97 & 1.22 & 1.29 & 2.4 & & \\
\hline Sc & 12 & 10 & 11 & 12 & 13 & 10 & 14 & 12 & 10 & & & \\
\hline Se & 1.05 & 0.61 & 1.3 & 0.85 & 1.09 & 0.64 & 1.37 & 0.81 & 0.77 & & & \\
\hline Sm & 3.1 & 1.35 & 7.8 & 8.0 & 8.8 & 1.35 & 5.5 & 3.4 & 4.3 & & & \\
\hline $\mathbf{S r}$ & 37.5 & 12 & 117 & 27 & 135 & 13 & 70 & 31 & 49 & & & \\
\hline $\mathbf{T a}$ & 2.0 & 1.6 & 1.6 & 2.1 & 2.1 & 1.1 & 2.7 & 1.8 & 1.6 & & & \\
\hline $\mathbf{T b}$ & 0.46 & 0.2 & 0.83 & 1.3 & 0.76 & 0.19 & 0.71 & 0.55 & 0.59 & & & \\
\hline Th & 22 & 11 & 17 & 20 & 17 & 11.2 & 30 & 20 & 17 & 1.8 & & \\
\hline $\mathbf{U}$ & 3.4 & 2.6 & 3.6 & 6.3 & 3.5 & 2.2 & 4.6 & 4.1 & 4.0 & 0.7 & & \\
\hline $\mathbf{V}$ & 129 & 63 & 101 & 83 & 116 & 72 & 152 & 129 & 123 & 48 & & \\
\hline $\mathbf{Y}$ & 24 & 8.4 & 19 & 25 & 21 & 8.1 & 21 & 29 & 31 & & & \\
\hline Yb & 2.6 & 1.7 & 1.9 & 4.2 & 1.6 & 1.3 & 2.8 & 2.9 & 3.3 & & & \\
\hline Zn & 63 & 31 & 53 & 41 & 73 & 26 & 65 & 57 & 37 & 97 & 109 & 130 \\
\hline $\mathbf{Z r}$ & 452 & 237 & 536 & 380 & 580 & 259 & 633 & 553 & 463 & & & \\
\hline \multicolumn{13}{|c|}{$(\%)$} \\
\hline $\mathrm{SiO}_{2}$ & 45.4 & 59.0 & 47.9 & 55.7 & 42.8 & 53.7 & 36 & 39.1 & 42.9 & & & \\
\hline $\mathrm{TiO}_{2}$ & 1.21 & 0.53 & 1.29 & 0.97 & 1.49 & 0.81 & 1.49 & 1.46 & 1.19 & & & \\
\hline $\mathrm{Al}_{2} \mathbf{O}_{3}$ & 28.3 & 24.5 & 29.5 & 25.5 & 30.6 & 25.6 & 31.2 & 35.4 & 27.6 & & & \\
\hline $\mathrm{Fe}_{2} \mathrm{O}_{3}$ & 7.70 & 4.60 & 6.54 & 6.58 & 8.1 & 5.82 & 9.60 & 7.17 & 6.17 & & & \\
\hline MnO & 0.02 & 0.03 & 0.04 & 0.04 & 0.03 & .03 & 0.02 & 0.02 & 0.01 & & & \\
\hline MgO & 0.26 & 0.13 & 0.45 & 0.28 & .38 & 0.24 & 0.21 & 0.28 & 0.29 & & & \\
\hline $\mathrm{CaO}$ & 0.24 & 0.13 & 0.20 & 0.07 & 0.38 & 0.19 & 0.30 & 0.23 & 0.09 & & & \\
\hline $\mathrm{Na}_{2} \mathrm{O}$ & 0.13 & 0.16 & 0.13 & 0.12 & 0.14 & 0.14 & 0.14 & 0.12 & 0.18 & & & \\
\hline $\mathbf{K}_{2} \mathbf{O}$ & 0.40 & 0.39 & 1.06 & 1.04 & 0.76 & 0.46 & 0.37 & 0.32 & 0.53 & & & \\
\hline $\mathrm{P}_{2} \mathrm{O}_{5}$ & 0.20 & 0.10 & 0.14 & 0.12 & 0.20 & 0.07 & 0.36 & 0.13 & 0.12 & & & \\
\hline
\end{tabular}


Fig. 2 presents the results obtained for the potentially toxic elements $\mathrm{As}, \mathrm{Ba}, \mathrm{Co}, \mathrm{Cr}, \mathrm{Cu}, \mathrm{Mo}$, $\mathrm{Ni}, \mathrm{Pb}, \mathrm{V}$ and $\mathrm{Zn}$ and the Quality Condition Values (VCQ) in soils of the metropolitan region of São Paulo, according to the governmental environmental agency of the state of São Paulo, CETESB $[25]$.

Figure 2: Trace Elements in São Paulo Public Parks and Guiding Values $\left(\mathrm{mg} \mathrm{kg}^{-1}\right)$.

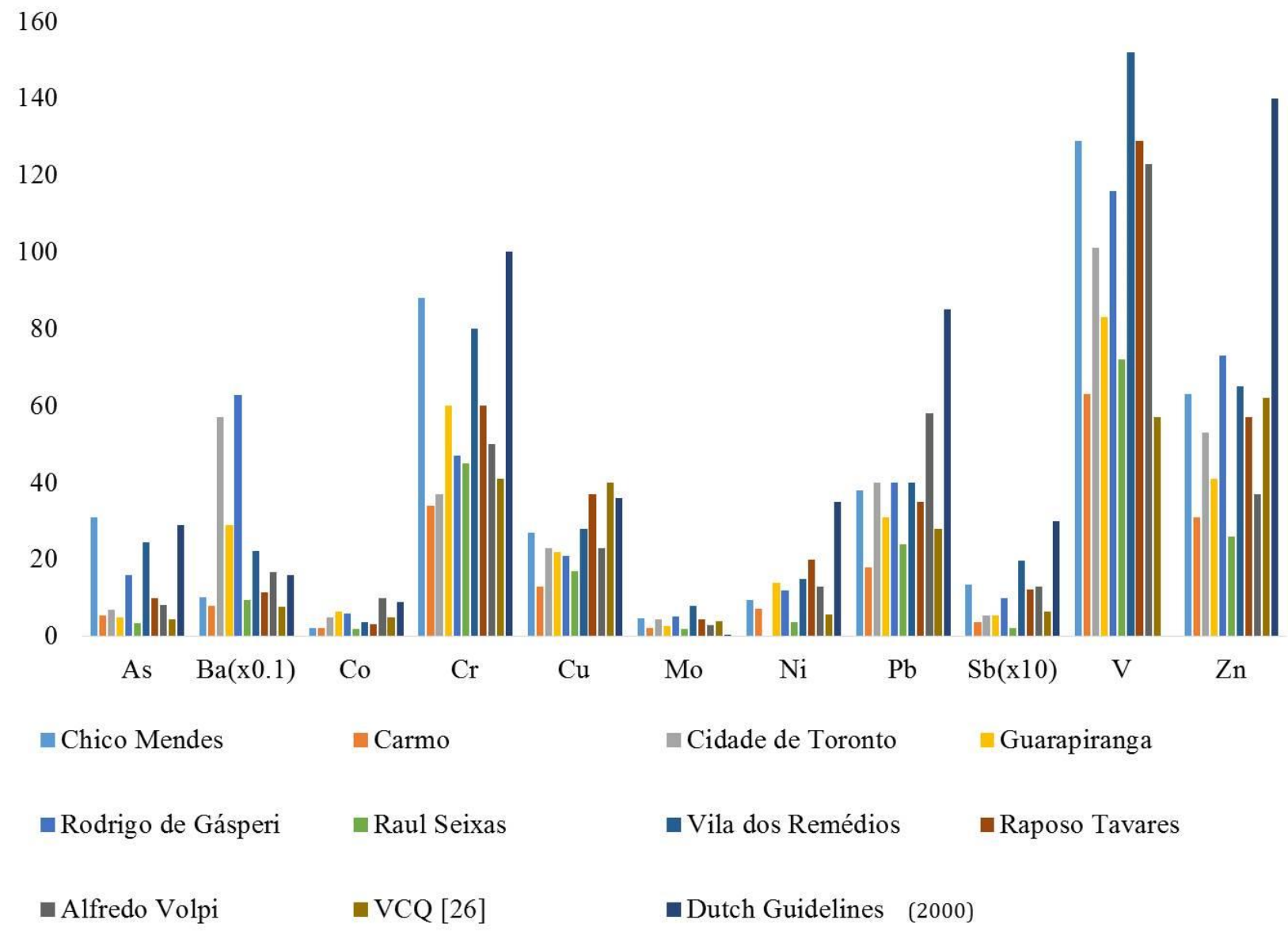

These values were defined based on the assessment of the characteristics of São Paulo state soils at almost pristine sites, i.e., without significant impacts of anthropogenic activities, and can be considered as background values. The results were also compared with the Netherlands Soil Contamination Guidelines, commonly referred to as the Dutch Soil Standard [26], often used as a standard in similar studies [27]. Soils with concentration levels below the Dutch target values are considered of sustainable quality. This means that soils are relatively unpolluted. According to the Dutch Soil Standard, concentrations exceeding the target value suggest that the soils may be contaminated. 
It can be observed that $\mathrm{As}, \mathrm{Ba}, \mathrm{Ni}, \mathrm{Sb}$ and $\mathrm{V}$ presented concentration levels higher than VCQ values in most parks, except As and Ni in Raul Seixas park, showing a significant increase compared to non urban soils. $\mathrm{Cu}$ presented concentration values below VCQ in all parks and $\mathrm{Cr}$ in Chico Mendes and Vila dos Remédios parks. Zn was higher than VCQ in Rodrigo de Gásperi and Vila dos Remédios parks.

In comparison to the Dutch guiding values, in general, all the studied elements presented concentration levels below the target values, except As in Chico Mendes park and Ba in Cidade de Toronto and Rodrigo de Gásperi parks. According to the Dutch Soil Standards, most of the parks are considered not polluted for the studied elements, except Chico Mendes park for As and Cidade de Toronto, Guarapiranga, Rodrigo de Gásperi and Vila dos Remédios parks, for Ba. The high results obtained for Ba in Rodrigo de Gásperi and Vila dos Remédios parks may be attributed to the lithology of these parks (granites, gneisses and migmatites), indicating a crustal origin of $\mathrm{Ba}$.

The enrichment factors were also calculated considering as geochemical background the Quality Condition Value (VCQ) [25]. Therefore, EF is the mean concentration of the element in the park in relation to VCQ in the metropolitan region of São Paulo (Table II).

Table II: Enrichment Factors in relation to VCQ values.

\begin{tabular}{|c|c|c|c|c|c|c|c|c|c|c|}
\hline Parks & As & $\mathbf{B a}$ & Co & $\mathrm{Cr}$ & $\mathbf{C u}$ & $\mathbf{N i}$ & $\mathbf{P b}$ & $\mathbf{V}$ & Sb & Zn \\
\hline $\begin{array}{l}\text { Cidade de } \\
\text { Toronto }\end{array}$ & 1.6 & 7.3 & 1.0 & 0.9 & 0.6 & 1.6 & 1.4 & 1.8 & 0.7 & 0.9 \\
\hline $\begin{array}{l}\text { Rodrigo de } \\
\text { Gásperi }\end{array}$ & 3.7 & 8.1 & 1.2 & 1.1 & 0.5 & 2.1 & 1.4 & 2.0 & 1.5 & 1.2 \\
\hline $\begin{array}{l}\text { Vila dos Re- } \\
\text { médios }\end{array}$ & 5.6 & 2.8 & 0.7 & 2.0 & 0.7 & 2.6 & 1.4 & 2.7 & 3.0 & 1.0 \\
\hline Guarapiranga & 1.1 & 3.7 & 1.3 & 1.5 & 0.6 & 2.5 & 1.1 & 1.5 & 0.8 & 0.7 \\
\hline $\begin{array}{l}\text { Chico } \\
\text { Mendes }\end{array}$ & 7.1 & 1.3 & 0.4 & 2.1 & 0.7 & 1.6 & 1.4 & 2.3 & 2.1 & 1.0 \\
\hline Carmo & 1.2 & 1.0 & 0.5 & 0.8 & 0.3 & 1.3 & 0.6 & 1.1 & 0.6 & 0.5 \\
\hline Raul Seixas & 0.8 & 1.2 & 0.4 & 1.1 & 0.4 & 0.6 & 0.9 & 1.3 & 0.4 & 0.4 \\
\hline Alfredo Volpi & 1.9 & 2.1 & 2.0 & 1.2 & 0.6 & 2.3 & 2.1 & 2.2 & 2.0 & 0.6 \\
\hline $\begin{array}{l}\text { Raposo } \\
\text { Tavares }\end{array}$ & 2.3 & 1.5 & 0.6 & 1.5 & 0.9 & 3.5 & 1.3 & 2.3 & 1.9 & 0.9 \\
\hline
\end{tabular}

The EFs were in general lower than 1 for $\mathrm{Cu}$ and $\mathrm{Zn}$, indicating a natural source for these elements in the studied soils. $\mathrm{Co}, \mathrm{Cr}, \mathrm{Pb}$ and $\mathrm{Sb}$ presented similar EFs in most the park soils (except $\mathrm{Sb}$ in Vila dos Remédios), showing an enrichment to clean soils but no indication of its origin. Ba pre- 
sented EFs of about 1 only in Carmo, Raul Seixas, Chico Mendes and Raposo Tavares parks. Nevertheless, the high $\mathrm{Ba}$ concentrations may be natural, due to the composition of the lithology of the region. In the case of $\mathrm{As}, \mathrm{V}$ and $\mathrm{Ni}$, which showed significant $\mathrm{EFs}$ in most parks, there is an indication of anthropogenic source.

The hierarchical dendrogram obtained by cluster analysis is shown in Fig. 3, where two main groups can be identified. The first group is integrated by the rare earth elements $\mathrm{Sr}$ and $\mathrm{Ba}$, indicating geogenic origin. The second group can be divided in two main sub-clusters, which are devided in sub-groups. It is remarkable that the traffic related elements $\mathrm{Zn}, \mathrm{Sb}, \mathrm{Cu}, \mathrm{Pb}$ and $\mathrm{Sn}$ are included in one sub-group, what may indicate vehicular source. The other sub-groups include the elements $\mathrm{U}, \mathrm{Y}, \mathrm{Ni}, \mathrm{Yb}$ and $\mathrm{Lu}$; Tb, Rb, Cs and Co, in one group and Se, Hf, Sc, Fe; Th, Zr, V, Nb, Ta, Mo, $\mathrm{Ga}$; $\mathrm{Cr}$ and $\mathrm{As}$ in other group. The fact that $\mathrm{As}$ and $\mathrm{Cr}$ are separated from the other elements indicate a common source, which may be the chromated copper arsenate (CCA) treated wood used in playground equipment's.

Figure 3: Cluster Analysis.

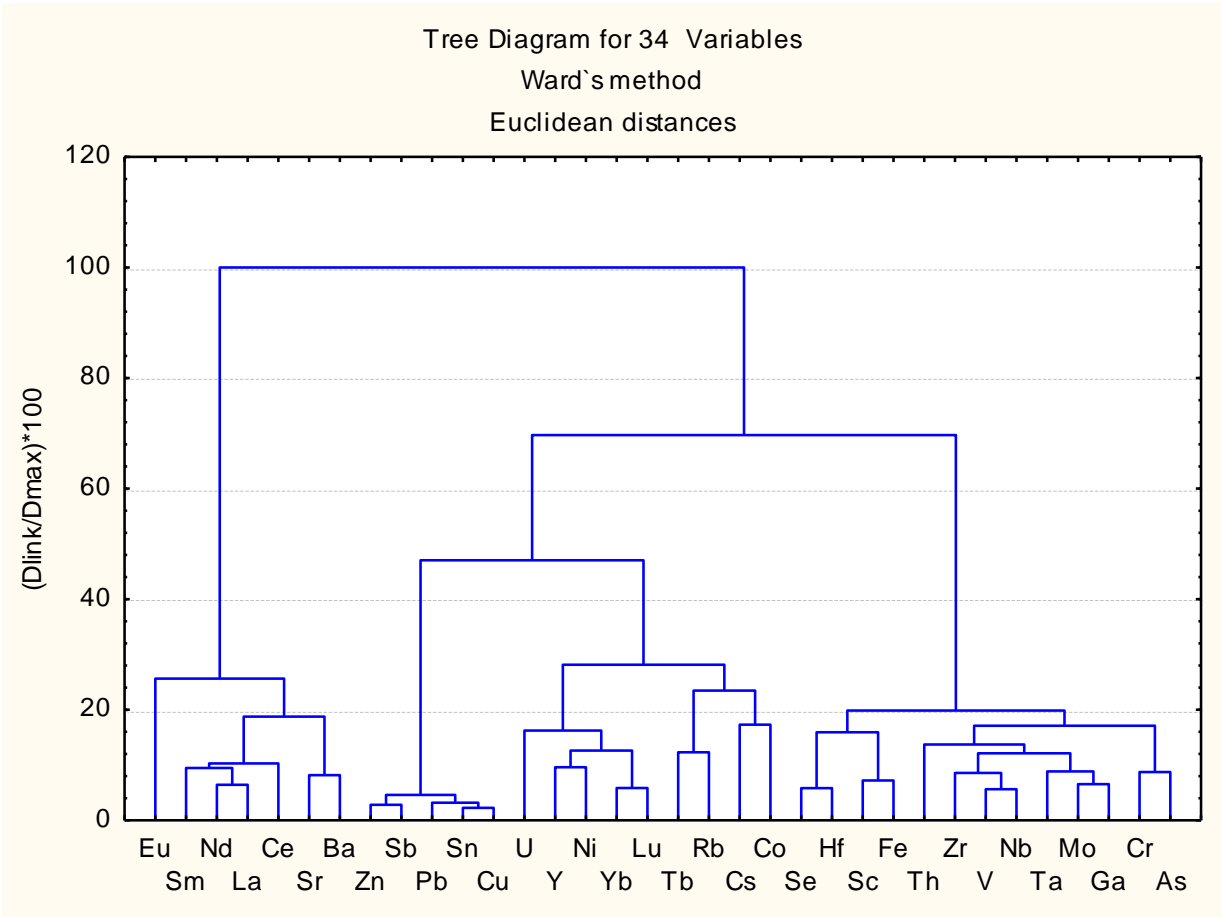

\section{CONCLUSION}


The results obtained showed that the soils of the nine São Paulo public parks studied presented, in general, concentration levels higher than the reference values for soils in São Paulo State. In comparison to the Dutch guiding values, in general, all the studied elements presented concentration levels below the target values. Arsenic presented higher levels in comparison to background levels and, in Chico Mendes park, higher than the target values of the Dutch standards, which corroborates to suggest an anthropogenic source. Cluster analysis showed the presence of $\mathrm{Zn}, \mathrm{Sb}, \mathrm{Pb}$ and $\mathrm{Cu}$, well known as traffic-related elements, in a separate group, which may indicate a vehicular source.

\section{ACKNOWLEDGMENT}

The authors thank Fundação de Amparo à Pesquisa do Estado de São Paulo and Conselho Nacional de Desenvolvimento Científico e Tecnológico for financial support.

\section{REFERENCES}

1. DE MIGUEL, E.; JIMÉNEZ DE GRADO, M.; LLAMAS, J.F.; MARTÍN-DORADO, A; MAZADIEGO, L.F. The overlooked contribution of compost application to the trace element load in the urban soil of Madrid (Spain). Sci Total Environ, v. 215, p. 113-122, 1998.

2. MANTA, D.S.; ANGELONE, M.; BELLANCA, A.; NERI, R.; SPROVIERI, M. Heavy metals in urban soils: a case study from the city of Palermo (Sicily), Italy. Sci Total Environ, 300, p. 229-243, 2002.

3. IMPERATO, M.; ADAMO, P.; ARIENZO, M.; STANZIONE, D.; VIOLANTE, P. Spatial distribution of heavy metals in urban soils of Naples city (Italy). Eviron Pollut, 124, p. $247-$ 256, 2003.

4. LEE, C.S.; LI, X.; SHI, W.; CHEUNG, S.C.; THORNTON, L. Metal contamination in urban, suburban, and country park soils of Hong Kong: A study based on GIS and multivariate statistics. Sci Total Environ, v.356, p.45-61, 2006.

5. SIALELLI, J.; DAVIDSON, C.M.; HURSTHOUSE, A.S.; AJMONE-MARSAN, F. Human bioaccessibility of $\mathrm{Cr}, \mathrm{Cu}, \mathrm{Ni}, \mathrm{Pb}$ and $\mathrm{Zn}$ in urban soils from the city of Torino, Italy. Environ Chem Lett, v.9, p.197-202, 2011. 
6. CACHADA, A.; DIAS, A.C.; PATO, P.; MIEIRO, C.; ROCHA-SANTOS, T.; PEREIRA, M.E.; FERREIRA DA SILVA, E.; DUARTE, A.C. Major inputs and mobility of potentially toxic elements contamination in urban areas. Environ Monit Assess, v.185, p. 279-294, 2012.

7. AJMONE-MARSAN, F.; BIASIOLI, M. Trace Elements in Soils of Urban Areas. Water Air Soil Pollut, v.213, p.121-143, 2010.

8. LEE, C.S.; LI, X.; SHI, W.; CHEUNG, S.C.; THORNTON, L. Metal contamination in urban, suburban, and country park soils of Hong Kong: A study based on GIS and multivariate statistics. Sci Total Environ, v.356, p. 45-61, 2006.

9. WONG, C.S.C.; LI, X.D.; THORNTON, I. Urban environmental geochemistry of trace metals. Environ Pollut, v.142, p.1-16, 2006.

10. MIELKE, H.W.; REAGAN, P.L. Soil is an important pathway of human lead exposure. Environmental Health Perspectives, v.106, p. 217-229, 1998.

11. MIELKE, H.W.; SMITH, M.K.; GONZALES, C.R.; MIELKE, P.W. The urban environment and children's health: soils as an integrator of lead, zinc and cadmium in New Orleans, Louisiana, U.S.A. Environmental Research, v.80, p. 117-129, 1999.

12. ABRAHAMS, P.W. Soils: their implications to human health. Sci Total Environ, v.291, p. $1-32,2002$.

13. LJUNG, K.; SELINUS, O.; OTABBONG, E. Metals in soils of children's urban environments in the small northern European city of Uppsala. Sci Total Environ, v.366, p.749-759, 2006.

14. RIBEIRO, A.P.; FIGUEIREDO, A.M.G.; TICIANELLI, R.B.; NAMMOURA-NETO, G.M.; SILVA, N.C.; KAKAZU, M.H.; ZAHN, G. Metals and semi-metals in street soils of São Paulo city, Brazil. J Radioanal Nucl Chem, v.291, p. 137-142, 2012.

15. FIGUEIREDO, A.M.G.; ENZWEILER, J.; CAMARGO, S.P.; SÍGOLO, J.B.; GUMIERO, F.C.; PAVESE, A.C.; MILIAN, F.M. Metal contamination in urban park soils of São Paulo. J Radioanal Nucl Chem, 280, p. 423-429, 2009.

16. CETESB, Relatório de qualidade do ar no Estado de São Paulo 2003 - São Paulo: CETESB, 2004. (Série Relatórios/ Secretaria de Estado do Meio Ambiente, ISSN 0103-4103).

17. IBGE, 2016. Instituto Brasileiro de Geografia e Estatística (Brazilian Institute of Geography and Statistics). Cidades. Available from: $<$ http://cidades.ibge.gov.br/xtras/perfil.php?codmun=3550308> Last accessed: 21.07.17 
18. ZAMBELLO, F.R.; ENZWEILER, J. Multi-element analysis of soils and sediments by wavelength-dispersive X-ray fluorescence spectrometry. J Soils Sediments, v.2, p. 29-36, 2002 .

19. LUO, X.S.; YU, S.; ZHU, Y.G.; LI, X.D. Trace metal contamination in urban soils of China. Sci Total Environ, v.421-422, p. 17-30, 2012.

20. CHIRENJE, T.; MA, L.Q.; SZULCZEWSKI, M.; LITTELL, R.; PORTIER, K.M.; ZILLIOUX, E. Arsenic Distribution in Florida Urban Soils: Comparison between Gainesville and Miami. J Environ Qual, v.32, p.109-119, 2003.

21. KABATA-PENDIAS, A.; PENDIAS, H. Trace elements in soils. Department at the University of Florida, Dr. Helena Solo- and plants. CRC Press, Boca Raton, FL,1992.

22. ENVIRONMENTAL PROTECTION AGENCY, Users' guide and background technical document for USEPA region 9's preliminary remediation goals (PRG) table, PRG 2004 Table. $<$ http://www.epa.gov/region09/waste/sfund/prg/index.html $>$ Last accessed: 21.07.17

23. HEMOND, H.F.; SOLO-GABRIELE, H.M. Children's exposure to arsenic from CCAtreated wooden decks and playground structures. Risk Analysis, v.24, p. 51-64, 2004.

24. CASARINI, S.C.P.; PINATTI, D.; LEMOS, L.C.; GAETA, M.M. Relatório de estabelecimento de valores orientadores para solos e águas subterrâneas no Estado de São Paulo: CETESB, São Paulo, 2001.

25. CETESB (São Paulo). Valores de condição da qualidade dos solos da bacia hidrográfica do Alto Tietê - UGRHI 6 e região metropolitana de São Paulo - RMSP/CETESB; São Paulo: CETESB, 70p., 2008 (Série Relatórios/CETESB, ISSN 0103403).

26. MINISTERIE VAN VOLKSHUISVESTING, RUIMTELIJKE ORDENING EN MILIEUBEHEER. Circular on Target Values and Intervention Values for Soil Remediation. Circular DBO/1999226863, Department of Soil Protection, Directorate-General for Environmental Protection, The Hague, 2000.

27. WONG, C.S.C.; Li X.D. Pb contamination and isotopic composition of urban soils in Hong Kong. Sci Total Environ, v.319, p.185-195, 2004. 